\title{
Compliance risks of industrial enterprises as a result of inefficiency of the institutional environment of the macro-region
}

\author{
Maria V. Golovko \\ dept. economic and socio-humanitarian disciplines, \\ National Research Nuclear University "MEPhI", \\ Volgodonsk Engineering Technical Institute, \\ Volgodonsk, Russian Federation, \\ golovko178@mail.ru
}

\author{
Valentina P. Kuznetsova \\ dept. industrial economics and finance \\ Russian state pedagogical University A. I. Herzen, \\ St. Petersburg, Russian Federation \\ vpr1000@yandex.ru
}

\begin{abstract}
This article examines the impact of institutional quality of the macro-region on the possibility of the formation of compliance risk industrial enterprises. The basic the regional ratings of the effectiveness of economic, political and social environment, published by the leading international organizations were analyzed. It is determined that negative dynamics remains in a number of positions, which is the starting point for further reforms. The materials of surveys conducted by the author at the regional and municipal levels were used. They confirm the objectivity of assessments of the quality of the institutional environment of the macro-region. Analysis of the current dynamics of the elements of the institutional environment led to the conclusion on the growth of the informal sector depending on the dynamics of indexes of safety in the institutional environment The results of the correlation analysis and model-building identified a strong correlation between the innovative development, level of economic freedom and levels of corruption. The examples and results management compliance risks in GK "Rosatom" on the basis of creation of system of intra-organizational control of observance of the operating system of rules in all functional and hierarchical planes of management was given.
\end{abstract}

Keywords - regional institutional environment, compliance risk, innovation index, corruption perceptions index, index of economic freedom

\section{INTRODUCTION}

The urgency of research on the effectiveness of the institutional environment is determined by the increase of the environment turbulence and the increase of uncertainty of economic development threats. An effective institutional environment is the environment that provides normal economic, political, socio-cultural conditions of the national economy and all its entities, sufficient for its conservation and sustainable development, and is the carrier of the security potential of the socio-economic system of any level. The converse case is also true, when its` irrelevance poses a threat to sustainable development and the integrity of the national economy.

The term "compliance risk", originally introduced in the banking sector, today is also used for the threat assessment of economic development of organizations in any industry. These threats are related to non-compliance with the legislation in force, with the establishment of insider control over financial flows, violation of internal rules and regulations while making management decisions. In other words, it is about illegal risks, risks of informality and regulatory risks that could lead to financial, reputational damage, sanctions by the public authorities and / or contractors.

The aim of the study presented in this article is to substantiate the negative impact of compliance risks generated as a result of an inefficient institutional environment on the innovative development of the macro-region economy. This will make it possible, according to the authors, to determine the priority directions of state and regional management of innovative development, to reduce the risks of inefficient use of limited resources allocated to stimulate innovative activity of enterprises. To achieve this goal, an analysis of authoritative domestic and foreign studies on the problems of inefficient institutional environment was carried out. It's the issues of G. Kaufman., Friedman E., Zoido-Lobaton P., Johnson S., Mohammed, A., A. Baranov, E. Malkov, L. Polishchuk, M. Rokhlin, Sunyaev, etc [1-11]. At the same time, the authors note the problem of shortage of reliable statistical estimates to determine the degree of development of compliance risks, primarily due to the fact that they are initially hidden. That is why it is quite difficult to assess the degree of their negative impact on the development of the macro-region, although it is obvious.

The authors of the article investigated the main obstacles to doing business at the Federal, regional and local levels, as well as an attempt to identify the relationship between the ineffectiveness of the institutional environment of the macroregion and the conditions of doing business. 


\section{MATERIALS AND METHODS}

To conduct the study we used the data of sociological surveys on the municipal and regional levels, as well as indicators of regional, national and international rankings, reflecting information on the institutional environment. The data was then processed using pacetti by Statsoft.

As a result of the correlation analysis revealed a close relationship between the individual indicators. Built linear regression model of dependence would reflect a high level of reliability model. The coefficients of the model and the equation are generally statistically significant. The resulting model was tested on data for two years.

\section{DISCUSSION}

The likelihood of compliance risks and its negative effects increase with intensification of negative influence of factors of the institutional environment. For example, the growth of corruption relations in the region could lead to the formation of corrupt schemes of interaction between the organization and contractors, authorities, because the problem is systemic, affecting directly and / or indirectly, all the participants of transactions. Distribution of illegal schemes of interaction between the participants of market exchange, being encouraged by corrupt officials, leads to habitualization of shadow practices in the economy, which increases the uncertainty and risks of the environment and leads to higher transaction costs, damages image and reduces competitiveness of Russian companies on the world market, etc.

These effects have a negative impact on the rating of the state positions, published by well-known organizations. Similar studies of factors and conditions of economic development are being conducted for a long time at both national and international level, interregional and crosscountry ratings of the effectiveness of existing conditions are being drawn up and its dynamics is being analyzed. Despite the fact that expert opinions are subjective, they are quite informative, comparative analysis reveals similarity in evaluation of indices and trends of its changes.

Table I lists the most popular cross-country indices assessing the quality and effectiveness of the institutional environment (World Bank, "Heritage" Foundation, Governance Research Indicator Country Snapshot (GRICS), International Country Risk Guide (ICRG) by Political Risk Services (PRS Group), the World Economic Forum, Transparency International, and others.). For ease of comparison of the dynamics of the indices, Table 1 shows not the values of the indices, but Russia's position in the ranking.

The positive dynamics of such an index as "Doing Business" deserves special attention in table 1 . The rationale for such a sharp increase in the ease of doing business index is that some of its indicators were included in the Road Map "Improving the quality of the regulatory business environment».
TABLE I. RUSSIAN FEDERATION RATINGS FOR THE PERIOD 2008-2016

\begin{tabular}{|c|c|c|c|c|}
\hline \multirow[t]{2}{*}{ Ratings } & \multicolumn{4}{|c|}{$\begin{array}{l}\text { Period and position of Russian } \\
\text { Federation in Rating }\end{array}$} \\
\hline & 2008 & 2011 & 2013 & 2016 \\
\hline $\begin{array}{ll}\text { Ease of Doing } & \text { Business } \\
\text { «Doing Business» } & \\
\text { (World Bank) [12] } & \\
\end{array}$ & 112 & 123 & 112 & 40 \\
\hline 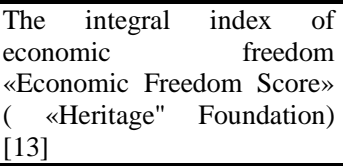 & 134 & 143 & 139 & 153 \\
\hline $\begin{array}{l}\text { Political and economic risks } \\
\text { «The International Country } \\
\text { Risk Guide» (PRS Group) } \\
{[14]}\end{array}$ & 48 & $\mathrm{n} / \mathrm{a}$ & 47 & $\mathrm{n} / \mathrm{a}$ \\
\hline $\begin{array}{l}\text { INSTEAD Global Innovation } \\
\text { Index [15] }\end{array}$ & $\mathrm{n} / \mathrm{a}$ & 56 & 62 & $\mathrm{n} / \mathrm{a}$ \\
\hline $\begin{array}{l}\text { The Global Competitiveness } \\
\text { Index (World Economic } \\
\text { Forum) [16] }\end{array}$ & 63 & 66 & 64 & 43 \\
\hline $\begin{array}{lr}\begin{array}{l}\text { Corruption } \\
\text { Index, }\end{array} & \text { Perceptions } \\
\text { International) } & \text { [17] }\end{array}$ & 147 & 143 & 127 & $\mathrm{n} / \mathrm{a}$ \\
\hline
\end{tabular}

The «Doing Business» index in Table 1 is of particular interest for us ${ }^{1}$. The rationale behind such a sharp increase $(20$ points) is the fact that some of its results were included in the Road Map "Improving the quality of the regulatory environment of business." Proof of this was the fact that as in all integral indices positive trend is not typical for each of the components, therefore, for some of them negative situation can remain unchanged. For example, in the above mentioned index such indicators as ease of obtaining credit, the level of investor protection and authorization insolvency decreased. Strong positive trend in the 2014 rankings, compared to 2013, of the "access to electricity" (an improvement of 67 points (!)), is due, in our opinion, to the inclusion of this category in the list of objectives of the above mentioned Road Map "Improving the quality of the regulatory environment for business" [18]. It is possible that the inclusion of the other rating parameters in the Road Map will lead to an increase in its value. In 2016, Russia managed to significantly improve the indicators in the field of registration of enterprises, customs regulation, but the indicators of international trade and obtaining a building permit remain a "growth zone" that requires the continuation of reforms.

At the regional level, the most popular is the evaluation of the environment, published by the rating agency "Expert RA". In particular, the investment attractiveness of the region is determined based on the investment potential and investment risk assessment. The investment risk is a qualitative characteristic that shows the probability of financial losses of investors, depending on the political, social, economic,

${ }^{1}$ Action Plan («Road Map») «Improving the quality of the regulatory environment for business» approved by the Decree of the Russian Government dated 11 June 2013г. №953-p [Electronic resource]. - Access 
financial, environmental and criminal situation. Table II shows the dynamics of the investment risks of the Rostov region, on the basis of which we can conclude on the increasing level of risk that has a negative impact on the investment attractiveness and, consequently, on the efficiency of doing business in the area.

TABLE II. INVESTMENT RISKS OF THE ROSTOV REGION FOR THE PERIOD 2011-2015

\begin{tabular}{|c|c|c|c|c|c|c|c|}
\hline \multirow[b]{2}{*}{ Year } & \multirow[b]{2}{*}{$\begin{array}{c}\text { Risk } \\
\text { Rang } \\
\end{array}$} & \multicolumn{6}{|c|}{ The ranks of the components of investment risk } \\
\hline & & 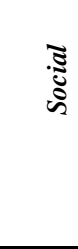 & 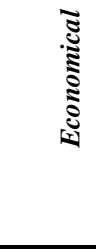 & 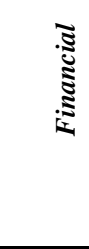 & 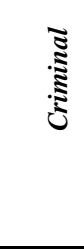 & 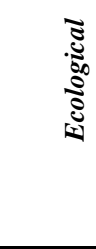 & 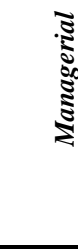 \\
\hline 2011 & 6 & 17 & 5 & 20 & 15 & 18 & 5 \\
\hline 2012 & 12 & 26 & 4 & 49 & 3 & 18 & 22 \\
\hline 2013 & 8 & 36 & 6 & 9 & 9 & 24 & 39 \\
\hline 2014 & 15 & 25 & 6 & 41 & 10 & 29 & 41 \\
\hline 2015 & 21 & 37 & 6 & 43 & 19 & 34 & 40 \\
\hline
\end{tabular}

a. Calculated by the author according to the agency "Expert RA"[Electronic resource].- Access mode:http://raexpert.ru/ratings/regions/ - Screen title.

According to the represented international and regional data, the quality of the institutional environment in Russia is negatively evaluated by experts, the similarity of estimates of its status and trends could be noted, and it also corresponds with the results of surveys conducted by the author at the municipal level (see Figure I), which gives these evaluations greater objectivity.

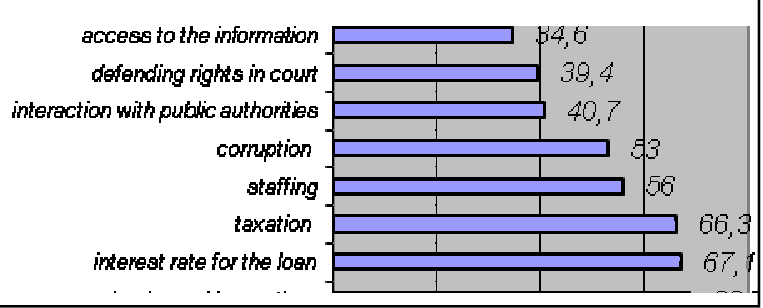

Fig. 1. Issues noted by entrepreneurs as the most acute, percentage of surveyed entrepreneurs in Volgodonsk, Rostov region (Survey results, conducted by the author)

On the basis of data in Tables I, II and Figure I it can be concluded on the systemic nature of the issues specific to the current institutional environment.

Reduced effectiveness of the institutional environment leads to increased compliance risks of economic development. As a result of these risks the dynamics of the informal sector can be considered. In assessing the applicability of formal rules as the regulation of economic activity, economic entities tend to offset the costs arising from this by participating in the informal sector. Thus, the positive dynamics of shadow economic relations reflects worsening of compliance risks of modern institutional environment. According to expert estimates, the change in the level of safety of individual components of the institutional environment leads to certain changes in the extent of economic offenses (Table III).

TABLE III. QUANTITATIVE RELIANCE OF THE EXTENT OF THE INFORMAL SECTOR ON THE CHANGE IN QUALITY OF SOME FACTORS OF THE INSTITUTIONAL ENVIROMENT

\begin{tabular}{|c|c|c|c|c|c|}
\hline Index & 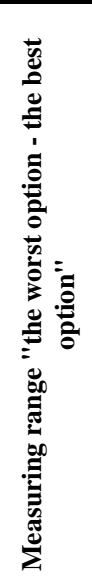 & 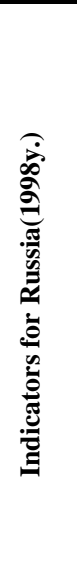 & 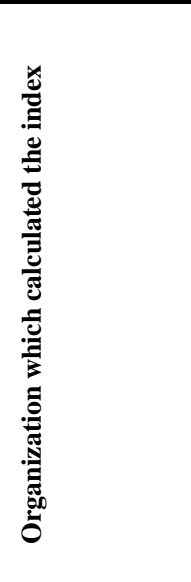 & 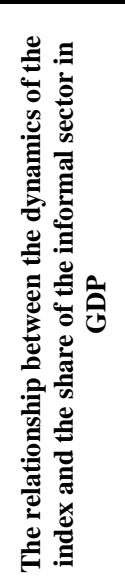 & 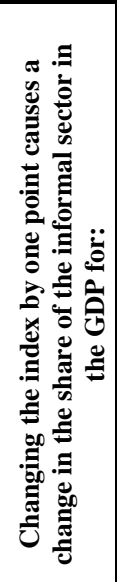 \\
\hline $\begin{array}{l}\text { Lawfulness } \\
\text { (mutual trust } \\
\text { b/w authorities } \\
\text { and society, } \\
\text { legal culture) }\end{array}$ & $0-6$ & 3,5 & $\begin{array}{l}\text { International } \\
\text { directory of } \\
\text { political risks }\end{array}$ & Inverse & $10,6 \%$ \\
\hline $\begin{array}{ll}\text { Quality } & \text { of } \\
\text { bureaucracy }\end{array}$ & $1-6$ & 3,19 & $\begin{array}{l}\text { International } \\
\text { directory of } \\
\text { political risks }\end{array}$ & Inverse & $8,5 \%$ \\
\hline $\begin{array}{l}\text { Economic } \\
\text { freedom }\end{array}$ & $0-16$ & 7,0 & $\begin{array}{l}\text { World Survey } \\
\text { of Economic } \\
\text { Freedom }\end{array}$ & Inverse & $2,5 \%$ \\
\hline $\begin{array}{l}\text { Degree of state } \\
\text { intervention in } \\
\text { the economy }\end{array}$ & $1-5$ & 4,0 & $\begin{array}{l}\text { "Heritage" } \\
\text { Foundation }\end{array}$ & Direct & $14,7 \%$ \\
\hline $\begin{array}{l}\text { Protection of } \\
\text { property rights }\end{array}$ & $5-1$ & 3,0 & $\begin{array}{l}\text { "Heritage" } \\
\text { Foundation }\end{array}$ & Direct & $13,4 \%$ \\
\hline $\begin{array}{l}\text { Arbitrariness } \\
\text { and unreliability } \\
\text { of officials }\end{array}$ & $1-7$ & 2,01 & $\begin{array}{l}\text { The World } \\
\text { Economic } \\
\text { Forum }\end{array}$ & Inverse & $9,2 \%$ \\
\hline $\begin{array}{l}\text { Corrupt } \\
\text { practices }\end{array}$ & $1-7$ & 2,72 & $\begin{array}{l}\text { TheWorldEco } \\
\text { nomicForum }\end{array}$ & Inverse & $8,0 \%$ \\
\hline $\begin{array}{l}\text { Equal } \\
\text { protection by } \\
\text { law and citizens' } \\
\text { access to legal } \\
\text { proceedings }\end{array}$ & $0-10$ & 2,5 & $\begin{array}{l}\text { FraserInstitut } \\
\mathrm{e}\end{array}$ & inverse & $3,8 \%$ \\
\hline Taxation & $10-1$ & 8,0 & $\begin{array}{l}\text { Fraser } \\
\text { Institute }\end{array}$ & Direct & $3,59 \%$ \\
\hline $\begin{array}{l}\text { Perception of } \\
\text { corruption }\end{array}$ & $0-10$ & 2,27 & $\begin{array}{l}\text { Transparency } \\
\text { International }\end{array}$ & Inverse & $5,1 \%$ \\
\hline
\end{tabular}


Analysis of the current dynamics of the elements of the institutional environment led to the conclusion on the growth of the informal sector by $14.47 \%$ compared to 1998 year. (Table IV).

TABLE IV. CALCULATION OF THE GROWTH OF THE INFORMAL SECTOR IN THE RELATION TO THE DYNAMICS OF THE MACRO-REGIONAL INSTITUTIONAL ENVIRONMENT INDICES OF THE SECURITY

\begin{tabular}{|c|c|c|c|c|c|}
\hline Index & 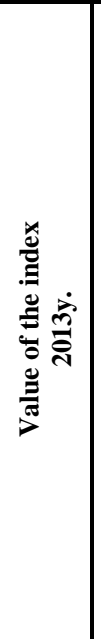 & 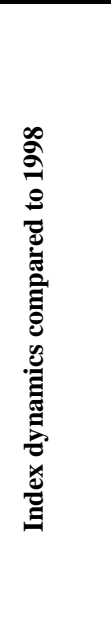 & 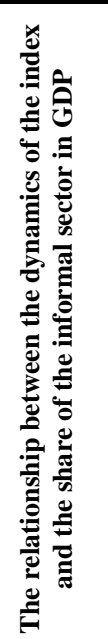 & 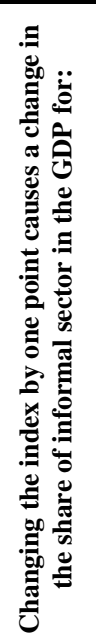 & 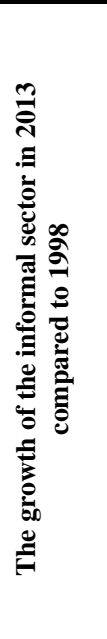 \\
\hline $\begin{array}{l}\text { Lawfulness } \\
\text { (mutual trust } \mathrm{b} / \mathrm{w} \\
\text { authorities } \quad \text { and } \\
\text { society, legal } \\
\text { culture) }\end{array}$ & 3,0 & $-0,5$ & Inverse & $10,6 \%$ & $+5,3 \%$ \\
\hline $\begin{array}{l}\text { Qualityofbureaucr } \\
\text { acy }\end{array}$ & 1,0 & $-2,19$ & Inverse & $8,5 \%$ & $+18,6 \%$ \\
\hline $\begin{array}{lr}\begin{array}{l}\text { Arbitrariness } \\
\text { unreliability } \\
\text { officials }\end{array} \\
\text { of } \\
\end{array}$ & 2,6 & $+0,59$ & Inverse & $9,2 \%$ & $-5,42 \%$ \\
\hline Corrupt practices & 3,1 & $+0,38$ & Inverse & $8,0 \%$ & $-3,04 \%$ \\
\hline $\begin{array}{l}\text { Equal protection } \\
\text { by law and } \\
\text { citizens' access to } \\
\text { legal proceedings }\end{array}$ & 2,6 & $+0,1$ & Inverse & $3,8 \%$ & $-0,38 \%$ \\
\hline Taxation & 8,02 & $+0,02$ & Direct & $3,59 \%$ & $+0,07 \%$ \\
\hline $\begin{array}{ll}\begin{array}{l}\text { Perception } \\
\text { corruption }\end{array} & \text { of } \\
\end{array}$ & 2,4 & $+0,13$ & Inverse & $5,1 \%$ & $-0,66 \%$ \\
\hline $\begin{array}{l}\text { Degree of state } \\
\text { intervention in the } \\
\text { economy * }\end{array}$ & \multirow{2}{*}{\multicolumn{2}{|c|}{$\begin{array}{l}\text { Positive } \\
\text { dynamics } \\
\text { of } \\
\text { indicators } \\
\text { compared to } \\
2012\end{array}$}} & Direct & $14,7 \%$ & $* * *$ \\
\hline $\begin{array}{l}\text { Protection of } \\
\text { property rights * }\end{array}$ & & & Direct & $13,4 \%$ & $* * *$ \\
\hline $\begin{array}{l}\text { In total: increase } \\
\text { in the informal } \\
\text { sector of the } \\
\text { economy }\end{array}$ & & & & & $+14,47 \%$ \\
\hline
\end{tabular}

${ }^{c}$ Indices and their dynamics are estimated based on reports and ratings published by organizations named in Table III.

Thus, according to J. Kaufmann [3], the informal sector of the Russian economy in 1998 amounted to $46.0 \%$ of GDP, in 2013 this proportion increased by $14.47 \%$ and amounted to about $60 \%$ of GDP (40 $025,1 \mathrm{mlrd}$. rub.). Even if taken as a basic minimum allowable level of the informal sector in the economy, determined in the amount of $10-15 \%$ of GDP, in 2013 this share reached about one third of GDP, which also carries a serious threat to the development of the national economy.

\section{RESULTS}

A high level of compliance risk of institutional environment negatively affects the possibility of innovative development of industrial enterprises. So, a close link between the scale of corruption component of the economy and the level of innovation development was identified and proven by the author. To identify and prove this correlation, the relationship between the Global Innovation Index (GII), the Corruption Perceptions Index (CPI) and the Index of Economic Freedom (EF) of 78 countries has been investigated. Correlation analysis revealed a close relationship between these indicators. According to data of 2012, a linear regression model of GIIs reliance on CPI was made, explained variation (coefficient of determination) amounted to $75.26 \%$ (Table V).

TABLE V. ANALYSIS OF THE RELATIONSHIP BETWEEN THE GLOBAL INNOVATION INDEX, CORRUPTION PERCEPTION INDEX AND THE INDEX OF THE ECONOMIC FREEDOM IN 2012-2014 AMONG THE 78 COUNTRIES

\begin{tabular}{|c|c|c|c|c|}
\hline Index Name & Year & GII & CPI & IEF \\
\hline & 2012 & \multirow{3}{*}{1} & & \\
\hline & 2013 & & & \\
\hline & 2014 & & & \\
\hline \multirow{3}{*}{$\begin{array}{l}\text { Corruption } \\
\text { Perception } \\
\text { Index(CPI) }\end{array}$} & 2012 & 0,86755 & \multirow{3}{*}{1} & \\
\hline & 2013 & 0,86063 & & \\
\hline & 2014 & 0,84868 & & \\
\hline \multirow{3}{*}{$\begin{array}{l}\text { Index of } \\
\text { Economic } \\
\text { Freedom (IEF) }\end{array}$} & 2012 & 0,66129 & 0,78089 & \multirow{3}{*}{1} \\
\hline & 2013 & 0,64589 & 0,77603 & \\
\hline & 2014 & 0,64369 & 0,77583 & \\
\hline
\end{tabular}

The coefficients of the model and the equation as a whole are statistically significant. Adding the second factor - the Index of Economic Freedom (EF) - to the model does not change the explained variation. On the basis of the constructed pair regression model calculation of theoretical values of GII was conducted, the relative approximation error was $8.52 \%$. The resulting model was tested on data from 2013 and 2014 (Figure II). 


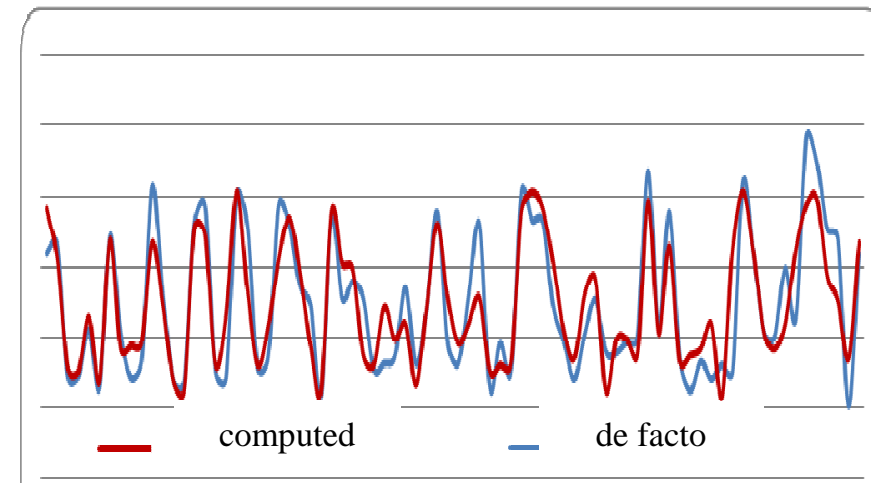

Figure II - Quality control model

The approximation error remained practically at the same level. The results show that there is a justified correlation between the Global Innovation Index (GII), which measures the country's position in the innovative development of the world community and opportunities for its sustainable development, and the Corruption Perceptions Index (CPI), which characterizes the assessment of the level of corruption perception by analysts and entrepreneurs.

Under the conditions of the innovative development of the compliance risks' reliance on the institutional environment and received latest estimates of its unsafe condition, the following conclusion can be drawn. The strategy of innovative development of industrial enterprises should include instruments which deter and eliminate compliance risks, as the project risks increasing factor arising at each stage of its implementation. The tools can be in the form of internal control procedures, risk assessment algorithms, risk insurance, references to the normative legal acts, etc. A good example is the mechanisms for monitoring compliance risks, integrated in corporate management system of GC "Rosatom". The authors of the article conducted research of the quality and results of the implementation of these mechanisms in the framework of the corporation $[19,20]$. For corporation, this mechanism is a priority, because the effectiveness of the projects (at the beginning of 2015 the company's portfolio included more than 20 projects totaling more than $\$ 50$ billion rub.) depends largely on the control of internal processes and resource flows.

To date, an integrated system of sectoral anti-corruption and asset protection operates in GC "Rosatom". In particular, the Road Map for the development of the compliance function in a corporation is approved, the system of internal control and audit is organized, activities aimed at prioritizing of compliance risks and identifying their owners, as well as activities of ideological and organizational character are carried out. The following obtained results can be named: in 2014 getting the effect from prevention and screening measures to protect assets (amounted for 5.3 billion rubles; in 2013 it was 5.1 billion rubles), the decrease by $11 \%$ in volume of transactions with deviations in valuation, $38 \%$ of appeals to the Central Arbitration Committee of the Corporation and arbitration committees and Electric Power fuel divisions abuse
Uniform industry procurement standard were considered reasonable ( in 2013 it was 30\%), as a result of inspections savings of $\$ 99$ million rubles were achieved (in 2013 it was 249 million rubles). Overall, during the period 2008-2014 control procurement system efficiency enabled to save about 250 billion rubles [21].

\section{CONCLUSION}

This example demonstrates the importance of intramonitor compliance with the existing rules of the system at all functional and hierarchical management levels. This control should become an integral element of the corporate system of values, contributing to the achievement of personal and overall efficiency.

\section{References}

[1] Friedman, E, S. Johnson, D. Kaufmann, and P. Zoido-Lobaton .Dodging the Grabbing Hand: the Determinants of Unofficial Activity in 69 Countries. Journal of Public Economics, 2000, Vol. 76, pp. 459-93.

[2] JohnsonS.,Kaufmann D. and Zoido-Lobaton P., Regulatory DiscretionandThe Unofficial Economy.American Economic Review, 1997May, 1997, pp.387-392.

[3] Johnson S., Kaufmann D., McMillan J., Woodruff C. (2000), Why Do Firms Hide? Bribes and Unofficial Activity After Communism, Journal of Public Economics, Vol. 76, June 2000, pp. 495 - 520.

[4] Anoop Singh, Sonali Jain-Chandra, and Adil Mohommad, Inclusive Growth, Institutions, and the Underground Economy. IMF Working Paper, 2012,12/47, February 1.

[5] R. Nicole, "Title of paper with only first word capitalized," J. Name Stand. Abbrev., in press.

[6] Y. Yorozu, M. Hirano, K. Oka, and Y. Tagawa, "Electron spectroscopy studies on magneto-optical media and plastic substrate interface," IEEE Transl. J. Magn. Japan, vol. 2, pp. 740-741, August 1987 [Digests 9th Annual Conf. Magnetics Japan, p. 301, 1982].

[7] M. Young, The Technical Writer's Handbook. Mill Valley, CA: University Science, 1989.

[8] G. Eason, B. Noble, and I.N. Sneddon, "On certain integrals of Lipschitz-Hankel type involving products of Bessel functions," Phil. Trans. Roy. Soc. London, vol. A247, pp. 529-551, April 1955. (references)

[9] J. Clerk Maxwell, A Treatise on Electricity and Magnetism, 3rd ed., vol. 2. Oxford: Clarendon, 1892, pp.68-73.

[10] I.S. Jacobs and C.P. Bean, "Fine particles, thin films and exchange anisotropy," in Magnetism, vol. III, G.T. Rado and H. Suhl, Eds. New York: Academic, 1963, pp. 271-350.

[11] A. Baranov, E. Malkov, L. Polishchuk, M. Rochlitz, Sunyaev, G.. Measuring institutions in? Russian regions: methodology, data sources, analysis [Baranov A., Malkov E., Polishchuk L., Rokhlits M., Syunyaev G.. Izmerenie institutov $\mathrm{v}$ rossiiskikh regionakh: metodologiya, istochniki dannykh, analiz]// Economic issues [Voprosy ekonomiki] 2015. - №2 - pp.38.

[12] Reports of the World Bank «Doing Business-2008», «Doing Business2012», «Doing Business -2013», «Doing Business -2014», «Doing Business -2016». [Electronic resource]. - Access mode: http://www.doingbusiness.org/. - Screen title.

[13] Index of Economic Freedom 2008-2016. - [Electronic resource]. Access mode: http://www.heritage.org/index/ranking. - Screen title.

[14] International Country Risk Guide.- [Electronic resource]. - Access mode: https://www.prsgroup.com/ICRG. - Screen title.

[15] Global Innovation Index - 2008, 2011; Global Innovation Index (The human factor in innovation) -2013, 2014. - [Electronic resource]. Access mode:http://www.globalinnovationindex.org/content.aspx?page=dataanalysis - Screen title. 
[16] Global Competitiveness Report 2008, 2011, 2013-2014 of World Economic Forum. - [Electronic resource]. - Access mode: http://www.weforum.org/reports/global-competitiveness-report2013-2014- Screen title.

[17] Corruption Perceptions Index 2008,2011,2013,2014.Transparency international Russia.Center for Anti-Corruption Research and Initiative.[Electronic $\quad$ resource]. $\quad$ - $\quad$ Access mode: $h$ htp://www.transparency.org.ru/indeks-vospriiatiia-korruptcii/ivk2008-2014- Screen title.

[18] Action Plan («Road Map») «Improving the quality of the regulatory environment for business» approved by the Decree of the Russian Government dated 11 June 2013г. №953-p [Plan meropriyatii («dorozhnaya karta») «Povyshenie kachestva regulyatornoi sredy dlya biznesa» utverzhden Rasporyazheniem Pravitel'stva RF ot 11 iyunya 2013g. №953-r] - [Electronic resource]. - Access mode: http://government.ru/info/779. - Screen title
[19] Golovko M., Kuznetcova V. Modern institutional environment: efficiency and economic security [Sovremennaya institutsional'naya sreda: effektivnost' i ekonomicheskaya bezopasnost']// Economy and Management [Ekonomika i upravlenie],2015, №10 (120), pp.19-23

[20] Golovko M., Rudenko V. Corporate values in the system of sustainable development and economic security of industrial enterprises (SC "Rosatom") [Korporativnye tsennosti v sisteme ustoichivogo razvitiya i ekonomicheskoi bezopasnosti promyshlennykh predpriyatii (GK "Rosatom")] // Global Nuclear Safety [Global'naya yadernaya bezopasnost'], 2015№4, pp. 103-114.

[21] According to the materials of public GC "Rosatom" reports for the 20082014 [Po materialam otchetov GK "Rosatom" za 2008-2014 gody].[Electronic resource]. mode:http://www.rosatom.ru/resources/0940a3004a03de62b0dff9e0386 2a3e4/anrep_rosatom_2014_public.pdf - Screen title. (lastaccessdate 10.05.2016). 